\title{
FIRST RECORD OF THE INVASIVE SEED BEETLE MEGABRUCHIDIUS TONKINEUS (COLEOPTERA, CHRYSOMELIDAE, BRUCHINAE) IN CROATIA
}

\section{IVAn Kurtek, Željko Zahirović, Nataša Turić, Ivana Vrućina, Goran Vignjević, Enrih Merdić \& Mirta Sudarić Bogojević} Department of Biology, Josip Juraj Strossmayer University of Osijek, Cara Hadrijana 8/A,
31000 Osijek, Croatia (e-mail: ivan.kurtek@gmail.com)

Kurtek, I., Zahirović, Ž., Turić, N., Vrućina, I., Vignjević, G., Merdić, E. \& Sudarić Bogojević, M.: First record of the invasive seed beetle Megabruchidius tonkineus (Coleoptera, Chrysomelidae, Bruchinae) in Croatia. Nat. Croat., Vol. 26, No. 1, 109-115, Zagreb, 2017.

The invasive seed beetle Megabruchidius tonkineus (Pic, 1904) is an agricultural pest native to the east Asian region that was first recorded in Europe (Germany) in the 1980s. There are further recent reports of this species from Bulgaria, France, Hungary, Russia, Serbia and Switzerland. Megabruchidius tonkineus resides in the seed pods of Gleditsia triacanthos L. (Fabaceae) and is recorded for the first time in Croatia in our study. The general morphological, biological and distributional features of this invasive species are given.

Keywords: Megabruchidius tonkineus, invasive species, new record, seed pods, Croatia

Kurtek, I., Zahirović, Ž., Turić, N., Vrućina, I., Vignjević, G., Merdić, E. \& Sudarić Bogojević, M.: Prvi nalaz invazivne vrste sjemenarki Megabruchidius tonkineus (Coleoptera, Chrysomelidae, Bruchinae) u Hrvatskoj. Nat. Croat., Vol. 26, No. 1, 109-115, Zagreb, 2017.

Invazivna vrsta sjemenarki porijeklom iz orijentalne Azije Megabruchidius tonkineus (Pic, 1904), nađena je po prvi puta u Hrvatskoj u mahunama gledičije (Gleditsia triachantos L.). Prvi nalaz ove vrste u Europi zabilježen je 80-ih godina prošloga stoljeća u Njemačkoj, međutim odnedavno postoje dokazi da se ta vrsta ustalila u Bugarskoj, Francuskoj, Mađarskoj, Srbiji i Švicarskoj. U radu su prikazana osnovna morfološka i biološka obilježja vrste kao i njezina rasprostranjenostna području Istočne Hrvatske.

Ključne riječi: Megabruchidius tonkineus, invazivna vrsta, novi nalaz, mahune, Hrvatska

\section{INTRODUCTION}

Bruchinae, or seed beetles, are presently assigned to the family Chrysomelidae (AnTon, 2010; GYörgy \& Germann, 2012). Their larvae develop in the seeds of plants, mostly Fabaceae. Several species have considerable agricultural importance, because their host plants are grown for human food or livestock fodder. The food trade plays important role in the world economy, but whenever food is traded, there is always a chance of foreign pests being introduced. In these days, there are frequent cases of unintended introduction of insect species with seeds coming from abroad but in most cases these events do not lead to the establishment of the newcomers. Unfortunately, this is not the case with $M$. tonkineus. According to the literature, this beetle was probably introduced to Eastern Europe by Vietnamese workers importing white beans from Asia (DeLOBEL \& Delobel, 2006, 2008). This invasive species was first recorded in Eastern Germany in 
1980. According to this record M. tonkineus failed to survive in Europe at that time), but after two decades there were several reports across Europe, from: Hungary (2002), Bulgaria (2007), France (2008), Russia (2011), Switzerland and Serbia (2012) (WENDT, 1980; Jermy et al., 2002; Jermy \& Szentesi, 2003; Wittenberg et al., 2006; Stojanova, 2007; Yus RAmos, 2009; GYörGY \& GERmanN, 2012). In all these countries M. tonkineus had infested the seed pods of the American tree honey locust (Gleditsia triacanthos), planted as a decorative plant all over Europe for more than 300 years (GENCSI \& VANCSURA, 1992). The native habitat of this beetle is east Asia where it develops in the seeds of Gleditsia australis, Dolichos lablab and Tagetes sp. (Southgate, 1979; Borowiec, 1984; György, 2007). The unique situation in Europe was than an Asian invasive species was feeding on American tree. It is clear that $M$. tonkineus can easily modify its feeding habits and adapt to new environments and climate changes, and there is cause for concern as to what will happen if this beetle starts consuming other food sources, including some economically important crops (Gavrilović \& Savić, 2013; Pešić, 2015b). Here we report the first finding of M. tonkineus and its distribution in Eastern Croatia.

\section{MATERIALS AND METHODS}

The fieldwork was carried out from January to February 2016. Gleditsia triacanthos seed pods were collected from 22 sites, which are shown in Tab. 1. On each site around 30 seed pods were collected from the ground. The available evidence suggests that seed pods that have fallen to the ground are a natural incubator for M. tonkineus (BorowiEc, 1984), and can be easily recognized by the specific emergence holes (Fig. 1). In the laboratory, seed pods were opened and searched for eggs, larvae or adults. Specimens were studied with an Olympus SZX16 stereoscopic microscope; photographs were taken with an Olympus DP25 camera. The images were processed by Cell` $\mathrm{D}$ imaging software. Books and papers that describe $M$. tonkineus were used for determination (SouthGATE, 1979; Borowiec, 1984; György, 2007; Stojanova, 2007; Korotyaev, 2011). After determination, some pod remains were transferred into insect cages in order to see whether adult specimens would be hatched.

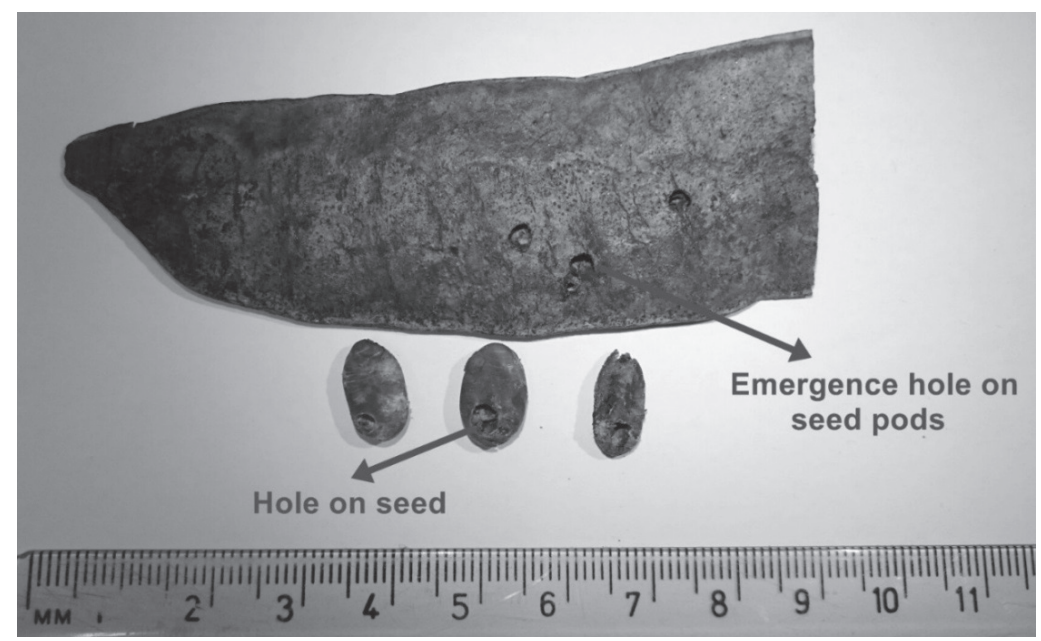

Fig. 1. Emergence holes on G. triacanthos seed pods 
Tab. 1: Sampling sites and GPS location

\begin{tabular}{|r|l|l|l|l|l|}
\hline no & Location name & GPS & no & Location name & GPS \\
\hline 1 & Osijek 1 & $45^{\circ} 35^{\prime} 42.77^{\prime \prime} \mathrm{S}, 18^{\circ} 44^{\prime} 28.54^{\prime \prime} \mathrm{I}$ & 12 & Mlaka Antinska & $45^{\circ} 22^{\prime} 43.35^{\prime \prime} \mathrm{S}, 18^{\circ} 46^{\prime} 22.06^{\prime \prime} \mathrm{I}$ \\
\hline 2 & Osijek 2 & $45^{\circ} 33^{\prime} 15.68^{\prime \prime} \mathrm{S}, 18^{\circ} 42^{\prime} 37.72^{\prime \prime} \mathrm{I}$ & 13 & Požega & $45^{\circ} 20^{\prime} 45.09^{\prime \prime} \mathrm{S}, 17^{\circ} 41^{\prime} 17.88^{\prime \prime} \mathrm{I}$ \\
\hline 3 & Darda & $45^{\circ} 37^{\prime} 12.59^{\prime \prime} \mathrm{S}, 18^{\circ} 41^{\prime} 16.96^{\prime \prime} \mathrm{I}$ & 14 & Trenkovo & $45^{\circ} 24^{\prime} 13.98^{\prime \prime} \mathrm{S}, 17^{\circ} 40^{\prime} 5.19^{\prime \prime} \mathrm{I}$ \\
\hline 4 & Čepin 1 & $45^{\circ} 31^{\prime} 58.27^{\prime \prime} \mathrm{S}, 18^{\circ} 31^{\prime} 54.68^{\prime \prime} \mathrm{I}$ & 15 & Koška & $45^{\circ} 32^{\prime} 43.48^{\prime \prime S}, 18^{\circ} 19^{\prime} 31.04^{\prime \prime I}$ \\
\hline 5 & Čepin 2 & $45^{\circ} 34^{\prime} 49.76^{\prime \prime} \mathrm{S}, 18^{\circ} 32^{\prime} 51.12^{\prime \prime} \mathrm{I}$ & 16 & Nemetin & $45^{\circ} 32^{\prime} 19.36^{\prime \prime S}, 18^{\circ} 47^{\prime} 8.72^{\prime \prime} \mathrm{I}$ \\
\hline 6 & Čepin 3 & $45^{\circ} 31^{\prime} 46.62^{\prime \prime} \mathrm{S}, 18^{\circ} 35^{\prime} 3.17^{\prime \prime} \mathrm{I}$ & 17 & Aljmaš & $45^{\circ} 32^{\prime} 46.67^{\prime \prime} \mathrm{S}, 18^{\circ} 59^{\prime} 7.92^{\prime \prime} \mathrm{I}$ \\
\hline 7 & Duga bara & $45^{\circ} 32^{\prime} 0.76^{\prime \prime} \mathrm{S}, 18^{\circ} 38^{\prime} 53.22^{\prime \prime} \mathrm{I}$ & 18 & Erdut & $45^{\circ} 31^{\prime} 41.26^{\prime \prime} \mathrm{S}, 19^{\circ} 3^{\prime} 56.72^{\prime \prime} \mathrm{I}$ \\
\hline 8 & Čeminac & $18^{\circ} 38^{\prime} 53.22^{\prime \prime} \mathrm{I}, 18^{\circ} 40^{\prime} 33.85^{\prime \prime} \mathrm{I}$ & 19 & Vukovar & $45^{\circ} 19^{\prime} 46.15^{\prime \prime S}, 19^{\circ} 2^{\prime} 36.71^{\prime \prime} \mathrm{I}$ \\
\hline 9 & Šećerana & $45^{\circ} 47^{\prime} 13.99^{\prime \prime} \mathrm{S}, 18^{\circ} 36^{\prime} 26.25^{\prime \prime} \mathrm{I}$ & 20 & Suza & $45^{\circ} 46^{\prime} 18.63^{\prime \prime S}, 18^{\circ} 45^{\prime} 47.77^{\prime \prime I}$ \\
\hline 10 & Tenja & $45^{\circ} 28^{\prime} 40.65^{\prime \prime} \mathrm{S}, 18^{\circ} 45^{\prime} 36.27^{\prime \prime} \mathrm{I}$ & 21 & Zmajevac & $45^{\circ} 48^{\prime} 22.95^{\prime \prime S}, 18^{\circ} 49^{\prime} 3.03^{\prime \prime} \mathrm{I}$ \\
\hline 11 & Korog & $45^{\circ} 24^{\prime} 49.69^{\prime \prime} \mathrm{S}, 18^{\circ} 45^{\prime} 18.28^{\prime \prime} \mathrm{I}$ & 22 & Batina & $45^{\circ} 52^{\prime} 59.25^{\prime \prime} \mathrm{S}, 18^{\circ} 52^{\prime} 12.44^{\prime \prime} \mathrm{I}$ \\
\hline
\end{tabular}

\section{RESULTS AND DISCUSION}

Megabruchidius tonkineus was first described as Laria tonkinea by PIC (1904). The literature did not mention this species of Oriental origin again for 73 years, until WENDT (1980) re-examined it and placed it in the genus Bruchidius. Four years later BorowiEc (1984) established genus Megabruchidius, based on the type species Megabruchidius bifoveolatus, which was there described as new species. In that paper, $M$. tonkineus was transferred into the genus Megabruchidius.

Adults are usually about $3-5 \mathrm{~mm}$ long. They can be easy recognized by the fair colouration in the dorsum (Fig. 2 a, c). Compared to females, males can be easily distinguished by the presence of a large round spot of short pale hairs on the abdominal sternite (Fig. 2 d), and by a notably convex and almost single-coloured pygidium (Fig. 2 c). Females can be recognized by presence of elongate impression along the edges of the slightly convex pygidium (Fig. 2 a). Also on the females, the hair spot could be confused because of setation of the same density that does not form a hair spot (Fig. 2 b). The first 5 antennomeres are light coloured in both sexes, slightly darker dorsally, while further antennomeres are fully black. The pronotum is elongated, not transverse, without a denticle bordered protrusion in the middle of the lateral margin. The elytra have small basal tubercles. In males the mesotibiae contain no apical denticles or plates; also the apex of metatibia has a mucro, which is typical mark for M. tonkineus (Fig. 2 e) (BorowIeC, 1984; György, 2007; Korotyaev, 2011).

When $M$. tonkineus was introduced to Europe, a very unusual situation occurred, in which an invasive Asian species invaded American trees on European soil, which is both remarkable and terrifying because this proves without a doubt that $M$. tonkineus is inherently invasive. In Europe this seed beetle has managed to find a completely new food source and somehow managed to survive the winters, which is remarkable for an insect native to a warmer climate. So far, $M$. tonkineus has prospered in Europe, the reason for which lies in the absence of any natural predators and parasitoids (Torchin et al., 2003). This new seed beetle is still not integrated in the European natural food chains. There are also a lot of concerns about $M$. tonkineus, because of its capacity to find other food 

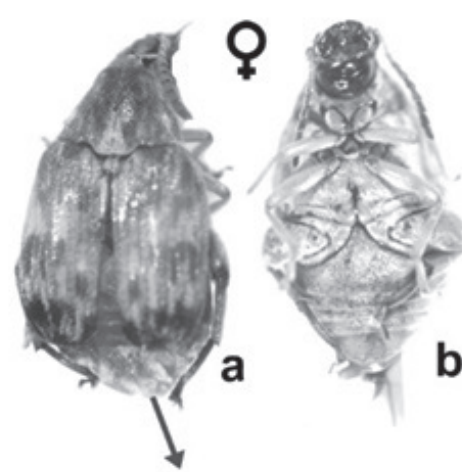

b

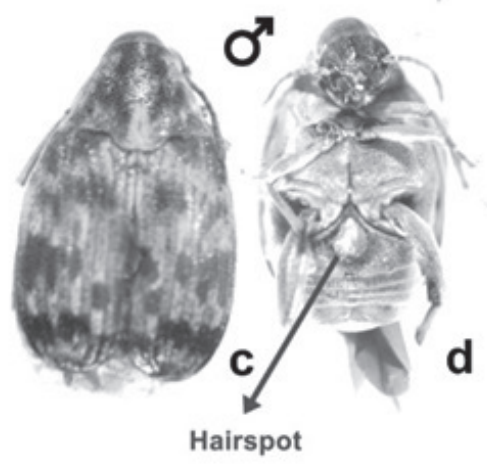

Pygidium
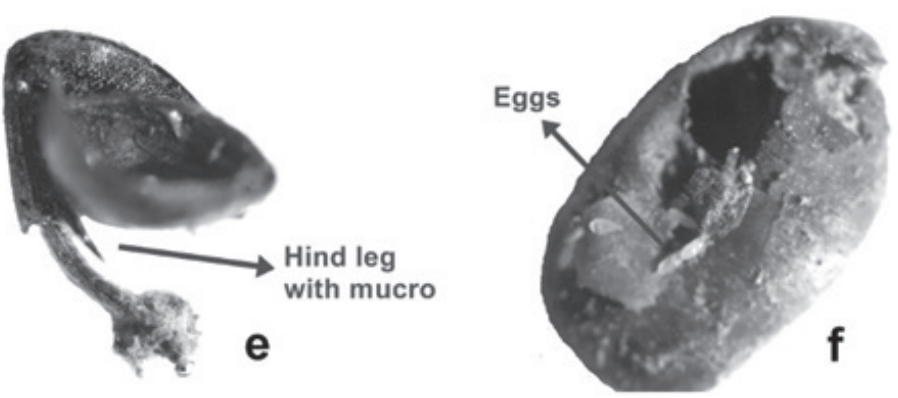

Fig. 2. (a,b) - female: dorsal and ventral view, $(\mathbf{c}, \mathbf{d})$ - male: dorsal and ventral view, $(\mathbf{e})$ - hind leg with mucro, (f) - G. triacanthos seed with hole
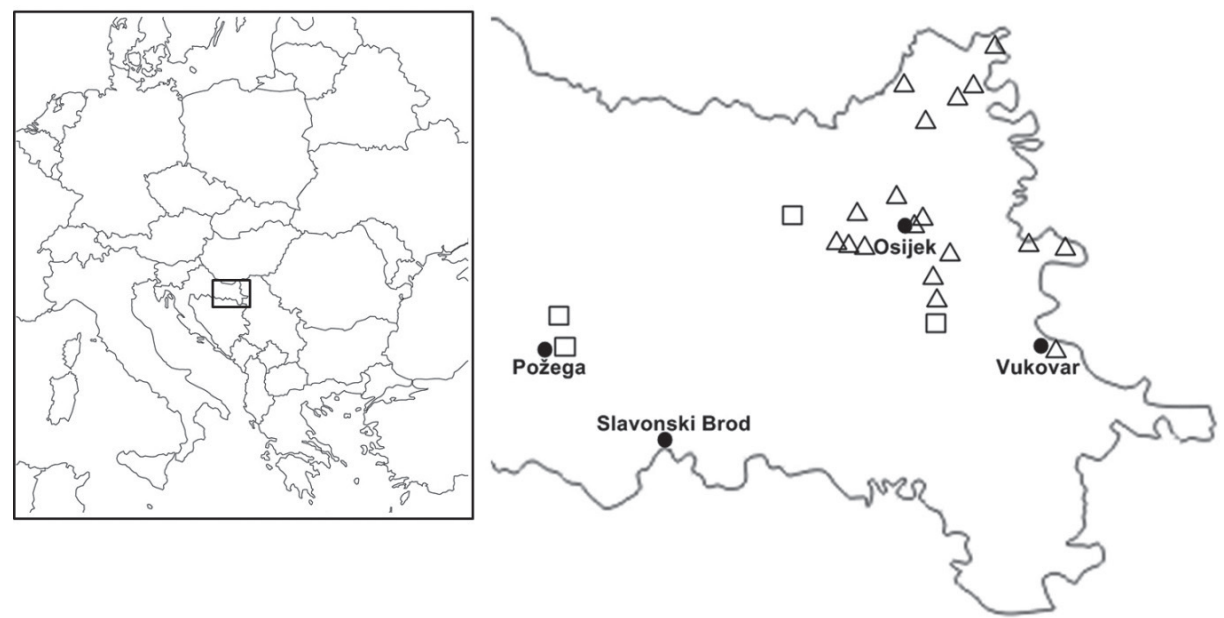

$\triangle$ Adults, eggs and holes on seed pods found $\square$ No record found

Fig. 3. Sampling sites 
Tab. 2: Number of adults and eggs collected from G. triachantos seed pods

\begin{tabular}{|c|c|c|c|c|c|c|}
\hline Date & Location name & Adults & $\begin{array}{l}\text { Holes on } \\
\text { seed pods }\end{array}$ & Eggs & Incubation & $\begin{array}{c}\text { Hatched } \\
\text { adults }\end{array}$ \\
\hline 21.01. & Osijek 1 & 1 & $\checkmark$ & $\checkmark$ & $\checkmark$ & 4 \\
\hline 28.01. & Osijek 2 & 2 & $\checkmark$ & $\checkmark$ & $\checkmark$ & 3 \\
\hline 01.02. & Darda & 3 & $\checkmark$ & $\checkmark$ & $\checkmark$ & 4 \\
\hline 04.02. & Čepin 1 & $x$ & $\checkmark$ & $\checkmark$ & $\checkmark$ & 9 \\
\hline 04.02 . & Čepin 2 & $x$ & $\checkmark$ & $\checkmark$ & $\checkmark$ & 5 \\
\hline 04.02. & Čepin 3 & 3 & $\checkmark$ & $\checkmark$ & $\checkmark$ & 6 \\
\hline 04.02. & Duga bara & $x$ & $\checkmark$ & $\checkmark$ & $x$ & $x$ \\
\hline 12.02. & Čeminac & 4 & $\checkmark$ & $\checkmark$ & $x$ & $x$ \\
\hline 12.02. & Šećerana & $x$ & $\checkmark$ & $\checkmark$ & $x$ & $x$ \\
\hline 15.02. & Tenja & $x$ & $\checkmark$ & $\checkmark$ & $x$ & $x$ \\
\hline 15.02. & Korog & $x$ & $\checkmark$ & $\checkmark$ & $x$ & $x$ \\
\hline 15.02. & Mlaka Antinska & $x$ & $x$ & $x$ & $x$ & $x$ \\
\hline 17.02. & Požega & $x$ & $x$ & $x$ & $x$ & $x$ \\
\hline 17.02. & Trenkovo & $x$ & $x$ & $x$ & $x$ & $x$ \\
\hline 17.02. & Koška & $x$ & $x$ & $x$ & $x$ & $x$ \\
\hline 18.02. & Nemetin & $x$ & $\checkmark$ & $\checkmark$ & $x$ & $x$ \\
\hline 18.02. & Aljmaš & 1 & $\checkmark$ & $\checkmark$ & $x$ & $x$ \\
\hline 18.02. & Erdut & $x$ & $\checkmark$ & $\checkmark$ & $x$ & $x$ \\
\hline 18.02. & Vukovar & $x$ & $\checkmark$ & $\checkmark$ & $x$ & $x$ \\
\hline 19.02. & Suza & $x$ & $\checkmark$ & $\checkmark$ & $x$ & $x$ \\
\hline 19.02. & Zmajevac & $x$ & $\checkmark$ & $\checkmark$ & $x$ & $x$ \\
\hline 19.02. & Batina & $x$ & $\checkmark$ & $\checkmark$ & $x$ & $x$ \\
\hline
\end{tabular}

sources. This could be some other plant from the Fabaceae family, like the pea (Pisum sativum) or bean (Phaseolus vulgaris), which has agro-economic importance. There are reports that $M$. tonkineus can also feed on vegetables and fruit remains in trash dumps, which offers a clue that the seed beetle could possibly change its food source in near future. Also there are health related concerns, because aggressive substances are produced in the $M$. tonkineus digestion process that can lead to allergic reactions in humans (Gagić Serdar et al., 2014; Pešić, 2015a). Because of its great potential to become a very serious pest, it is necessary to survey this invasive seed beetle, especially its feeding habits, abundance, population dynamics and distribution.

Since fieldwork was carried during winter, which is not the best season to collect insect samples, we expected to find only fragments or, at best, dead adult specimens or eggs. In the field we focused on $G$. triacanthos seed pods containing emergence holes. Without any doubt, those emergence holes indirectly confirm the presence of invasive $M$. tonkineus even if adult seed-beetles were not present. This is because various species of Gleditsia (including G. triacanthos) contain 5-hydroxypipecolic acid 
(ReHr et al., 1973) and triterpenoid saponins (Konoshima et al., 1995), which are toxic for most non-adapted insects and other seed predators. However, they apparently do not affect $M$. tonkineus. Fourteen adult specimens of $M$. tonkineus were found inside seed pods collected from various locations, three of them were alive; in addition, eggs were found in all seed pods containing emergence holes. Eggs were mostly found on seeds and on the inner seed pod wall just under the emergence holes. According to the literature, the eggs are yellow, elongated and ovoid with one edge pointed, the other rounded. The length is an average of $0.831 \mathrm{~mm}$, and the width an average of $0.317 \mathrm{~mm}$. The egg shell is finely punctate (Fig.2 f) (Borowiec, 1984). Fieldwork results are shown in Tab. 2.

After the presence of adult specimens, eggs too were confirmed. The seed pod remains from the first six locations were transferred into insect cages for incubation in laboratory, moisture in the cages being retained with moist pieces of cotton. Hatched adults additionally confirm the presence of $M$. tonkineus, and the results of incubation are shown in Tab. 2. With this research we manage to cover 21 locations, so this paper also provides an initial view about the distribution of M. tonkineus in eastern Croatia (Fig. 3). This map provides initial data about the possible spread of M. tonkineus into Croatia from Serbia and Hungary since those countries already have records of this Asian invasive species. Further research is needed to confirm the presence of this invasive species in other parts of Croatia.

Received January 23, 2017

\section{REFERENCES}

Anton, KW., 2010: Family Bruchinae. Löв, I. \& Smetana, A. (eds). Catalogue of Palaearctic Coleoptera. Vol. 6. Chrysomeloidea. Stenstrup: Apollo Books, pp 339-353.

Borowiec, L., 1984: Two new genera and species of seed-beetles from the Oriental Region (Coleoptera, Bruchidae, Bruchinae). Polskie Pismo Entomologiczne 54, 115-129.

Delobel, B. \& Delobel, A., 2006: Dietary specialization in European species groups of seed beetles (Coleoptera: Bruchidae: Bruchinae). Oecologia 149 (3), 428-443.

Delobel, P. \& Delobel, A., 2008: Une nouvelle Bruche asiatique importée en France: Megabruchidius tonkineus (Pic, 1904) (Coleoptera: Bruchinae). Bulletin de la Société Entomologique de France 113(2), 227-229.

Gagić Serdar, R., Mihajlović, Lj., Poduška, Z., Đorøević, I., Češljar, G., Bilibajkić, S., Stefanović, T., Milosavljević, M. \& Nevenić, R., 2014: Seed pedation in legominous trees and shrubs: New invasive beetles (Coleoptera: Chrysomelidae: Bruchinae) to Serbian fauna. Agriculture \& forestry. Vol 60 issue 3, Podgorica, 163- 174.

Gavrilović, B. \& SAvić, D., 2013: Invazivne Bruchinae nove za faunu Srbije. Symposium of entomologist of Serbia, Tara, 18-22.11.2013. pp.14.

Gencsi, L. \& VAscura, R., 1992: Dendrologia (Dendrology) - Mezögazda, Budapest, 728pp.

György, Z., 2007: To the Biology of the Honey Locust Seed Beetle, Megabruchidius tonkineus (Pic, 1904) (Coleoptera: Chrysomelidae: Bruchinae). Folia Entomol. Hung. 68, 89-96.

György, Z. \& Christoph, G., 2012: First record of Megabruchidius tonkineus (Pic, 1904) for Switzerland. Mitteilungen der Schweizerischen Entomologischen Gesellschaft 85, 243-249.

Jermy, T., Szentesi, Á. \& Anton, KW., 2002: Megabruchidius tonkineus (Pic, 1904) (Coleoptera: Bruchidae) first found in Hungary. Folia entomologica hungarica 63, 49-51.

Jermy, T. \& SzEnTESI, Á., 2003: Evolutionary aspects of host plant specialisation a study on bruchids (Coleoptera: Bruchidae). Oikos, 101, 196-204.

Konoshima, T., Yasuda, I., Kashiwada, Y., Cosentino, LM. \& LeE, KH., 1995: Anti-AIDS agents. 21. Triterpenoid saponins as antiHIV principles from fruits of Gleditsia japonica and Gymnocladus chinensis, and a structure-activity correlation. Journal of Natural Products 58(9), 1372-1377. 
Korotyaev, BA., 2011: On Invasion of an East Asian Seed Beetle, Megabruchidius tonkineus (Pic, 1904) (Coleoptera, Bruchidae), Developing in Gleditsia Seeds, in the Northwest Caucasus. Entomological Review 91(9), 1167-1169.

Pešıć, S., 2015a: Tajna uspeha Megabruchidius tonkineus (Pic, 1904), Ekološka rešenja. X simpozijum entomologa Srbije, Kladovo 23-27.09.2015, Zbornik plenarnih referata I rezimea 3-4.

Pešıć, S., 2015b: Tajna uspeha Megabruchidius tonkineus (Pic, 1904), reproduktivna rešenja. X simpozijum entomologa Srbije, Kladovo 23-27.09.2015, Zbornik plenarnih referata I rezimea 5-6.

Rehr, SS., Bell, EA., JAnzen, DH. \& FeenY, PP., 1973: Insecticidal amino acids in legume seeds. Biochemical Systematics 1, 63-67.

Southgate, BJ., 1979: Biology of the Bruchidae. Annual Review of Entomology 24, 449-473.

Stojanova, A., 2007: Megabruchidius tonkineus (Pic, 1904) (Chrysomelidae: Bruchinae), a New Seed Beetle to the Bulgarian Fauna. Acta Zoologica Bulgarica 59 (1), 109-110.

Torchin, M., Laferty, K., Dobson, A., McKenzie, V. \& Kuris, A., 2003: Introduced species and their missing parasites. Nature 421, 628-630.

Wendt, H., 1980: Erstmaliges Auftreten des Vorratsschädlings, Bruchidius tonkineus (Pic, 1904) in der DDR. Deutsche Entomologische Zeitschrift 27, 317-318.

Wittenberg, R., Kenis, M., HängGi, A. \& Weber, E., 2006: Invasive alien species in Switzerland. An inventory of alien species and their threat to biodiversity and economy in Switzerland. CABI Bioscience Switzerland Centre report to the Swiss Agency for Environment, Forests and Landscape. The environment in practice no. 0629. Federal Office for the Environment, Bern, 155 pp.

Yus Ramos, R., 2009: Revisión del género Megabruchidius Borowiec, 1984 (Coleoptera: Bruchidae) y nuevas citas para Europa. Boletín de la Sociedad Entomológica Aragonesa 45, 371-382. 